\title{
The Influence of Service Quality on inpatients Satisfaction: Study at Bahagia Hospitals, Makassar City
}

\author{
Herlina Sakawati ${ }^{1}$, Nina Agustina ${ }^{2}$, Sulmiah $^{3}$ \\ ${ }^{1,2,3}$ Public Administration Study program, Faculty of Social Science Universitas Negeri \\ Makassar \\ Email: herlinamappakanro@gmail.com
}

\begin{abstract}
This study aims to determine the effect of service quality on inpatient satisfaction at the Bahagia Hospital in Makassar City. The research method used is a quantitative survey method using an explanatory approach. A sample of 100 people who are inpatients at the Bahagia Hospital using accidental sampling technique. The data analysis used is descriptive analysis and inferential analysis. The results showed that the quality of service had a significant influence on the satisfaction of inpatients at the Bahagia Hospital. This shows that service quality has an important role so that service delivery can provide results in accordance with what patients expect.
\end{abstract}

Keywords: Service Quality Inpatients and Patient Satisfaction

\section{INTRODUCTION}

The Law of the Republic of Indonesia Number 25 of 2009 concerning Public Services explains that public services are activities to fulfill the needs of society for goods, services and administrative services in accordance with the prevailing laws and regulations. The law also explains that every citizen has the right and obligation to obtain services that are fair, not discriminatory, and prioritize the needs of the community (Akib \& Ihsan, 2017; Van Gobel et al., 2015). The current service most needed by the community is in the health sector, considering that health is one of the important factors in people's lives (Agency for Toxic Substances and Disease Registry, 2015; Pittman, 2016).

The hospital is a health service facility that can be administered by the government or private sector (Heywood \& Harahap, 2009; Institute for Public Health Malaysia, 2015; Lahey, 2009). Health services in hospitals can be in the form of outpatient services, inpatient services, and emergency care services which include medical services and non-medical services.

The Bahagia Hospitalis a private public hospital located in the city of Makassar. At the beginning of its establishment, the hospital was a special hospital which was later changed to become a general hospital. These changes were made so that the Bahagia Hospital can help people who need excellent and complete health services, which emphasize the ability to be fast, precise, accurate, reliable, and professional at an affordable cost. However, these things cannot be fulfilled by Bahagia Hospital because there are still many patient complaints related to the quality of service provided by the hospital.

The problems that occur at the Bahagia Hospital are based on observations that have been made, namely the attitude of the administrative staff who are not polite, doctors are hard to find, there is a bad smell in some treatment rooms, facilities and infrastructure are still lacking, and 


\section{Jurnal Office: Jurnal Pemikiran Ilmiah dan Pendidikan Administrasi Perkantoran Vol. 7, No. 1, January-June 2021, Hal 21-28}

the attitude of doctors and nurses who are not friendly. , fast and responsive in providing services. This was also reinforced by one of the news released by the online media on December 26, 2019, where the news article explained about a doctor's unethical treatment of one of the patients which resulted in the patient leavingthe hospital forcibly, (Sirata, 2019) From the results of the above observations, it can be concluded that the community as service users have not received quality health services so that people are still not satisfied with the services received, this is contrary to Law Number 36 Year 2009 and Law Number 44 Year 2009. Problems This is also not in line with the reasons for the change from a special hospital to a general hospital, where the change was made to meet the needs of the community for excellent and complete health services.

The data for inpatients at the Bahagia Hospital from 2016-2019 were obtained from hospital medical record data, which are as follows:

Table 1.1

Number of Inpatients at Bahagia Hospital

\begin{tabular}{ccc}
\hline No. & Year & Total \\
\hline 1. & 2016 & 3965 \\
2. & 2017 & 4045 \\
3. & 2018 & 4855 \\
4. & 2019 & 5762 \\
\hline
\end{tabular}

From the data above, it can be seen that the number of hospitalized patients from 20162019 continues to experience a significant increase. This happens because the community's need for health services continues to increase every year. From the data above, it can also be seen that the increase in inpatients that occurs cannot be used as a benchmark to measure the quality of service. Therefore, this study will focus on inpatients to determine the level of patient satisfaction with the health services provided by the hospital.

Various problems regarding the quality of health services in hospitals have been carried out by many previous researchers. As was done by Musniah (2015) who examined the relationship between the quality and satisfaction of BPJS users at Polewali Mandar Hospital, and Nova (2010) who examined the Quality of Health Services on Inpatient Satisfaction at PKU Muhammadiah Hospital, Surakarta. This study is different from research that has been conducted by previous researchers where the differences lie in the locus, focus and theory used. Departing from several theories, ideas from previous research, a study was conducted with the title "The Effect of Service Quality on Inpatient Satisfaction: A Study at the Bahagia Hospital Makassar City

\section{METHOD}

Variabel This research is an explanatory research using a quantitative approach. The variables studied were service quality and patient satisfaction. The sample taken in this study 
were 100 respondents who were inpatients at the Bahagia Hospital. The sampling technique used was accidental sampling. The data was collected using a questionnaire that has been tested for validity and reliability and using documentation (Ayu et al., 2019; Saleh et al., 2019) in the form of hospital activity reports, photographs, and data from hospital archives that are relevant to the research. Then the data analysis technique used descriptive analysis and inferential analysis to see the quality of service and satisfaction of inpatients and to see influence of service quality and patient satisfaction.

\title{
RESULT AND DISCUSSION
}

Data This study consisted of 100 respondents, there were 24 male respondents and 76 female respondents. This study shows that the dominant age of the respondents is between 21 and 40 years, as many as 61 people, with the dominant occupation as a housewife

\section{Quality of inpatient services at the General Hospital Bahagia Makassar City}

Service quality is a dynamic condition related to products, services, people, processes and the environment where quality assessment is determined at the time the service is provided. To analyze the quality of service for inpatient satisfaction at the Bahagia Hospital in Makassar City, Zeuthaml et.al's theory in Hardiansyah (2018) is used with five dimensions, namely: Tanggible, Reliability, Responsivenes, Assurance, and Empathy. The results showed that the quality of service can be seen from the following description:

\begin{abstract}
Assurance
Assurance is the knowledge, ability, friendliness and trustworthiness possessed by officers to provide services with trust and confidence and free from danger, risk and doubt, skill and trust (Ankeney, 1981; Frazer, 2003; Pollard, 2003; Stevenson, 2017). The result of the research shows that the guarantee indicator is in a very good category and is the indicator with the highest percentage value among the five indicators used. This means that most of the respondents agreed and strongly agreed with the quality assurance of services provided by Bahagia Hospital. From the description above, it can also be concluded that the care provided by nurses and the medication provided by doctors is always guaranteed safety and that the information needed by patients and their families is always provided clearly and accurately, so that patients and families are satisfied with the services provided by the hospital. This is in line with the opinion expressed by Supriyanto \& Ernawati (2010) regarding the knowledge, politeness and ability of officers in providing services to the community so that it can foster a sense of public trust and confidence in the security of each service provided.
\end{abstract}

\section{Reliability}

Reliability, namely the ability to provide services as expected accurately and satisfactorily, promises are kept according to schedule and the diagnosis is proven to be accurate (Niswaty et al., 2020; Salam et al., 2014; Zalatar, 2017). The results of the study indicate that the Reliability indicator is in the very good category and is a variable indicator with the second highest percentage value of the five variable indicators used. This means that the average respondent gives an agreeable response to the Realibility indicator variable. From this description, it can be 


\section{Jurnal Office: Jurnal Pemikiran Ilmiah dan Pendidikan Administrasi Perkantoran Vol. 7, No. 1, January-June 2021, Hal 21-28}

concluded that doctors, nurses and medical support officers at the Bahagia Hospital are reliable in providing medication and care to patients, so that patients and their families are satisfied with the quality of service provided by the hospital. In addition, the diagnosis and admission procedures are accurate and straightforward. This is in line with the results of research conducted by Supartiningsih (2017) which states that the reliability variable has a positive effect on patient responses related to services provided by doctors, nurses and medical support officers.

\section{Tanggible}

Tanggible is characterized by the adequate provision of human resources and other resources (Bircan \& Gençler, 2015; Björkman \& Lu, 1999; Lamin \& Livanis, 2020). The results of the study indicate that the Tanggible variable indicator is in the very good category and is the variable indicator with the third highest percentage value of the five variables used. This proves that the average respondent gives an agreeable response to the Tanggible variable. From this description, it can be interpreted that the appearance of doctors and nurses, the condition of the treatment room, the condition of the parking lot, the availability of medical support facilities and the timeliness of feeding at the Bahagia Hospital can be said to be very good. In line with research conducted by Idris E (2012) states that the Tanggible variable has a positive effect on patient satisfaction. Comfort is also important because it can affect patient confidence in health care. Comfort is closely related to a beautiful environment, cleanliness of the room, cleanliness of toilets, room amenities, medical equipment and cleanliness of food and beverages. Comfort is an important factor in attracting patients who can guarantee continuity of treatment and the comfort of a form of service that cannot be seen and touched. This is in accordance with the opinion expressed by Suryawati (2006): "Tanggible can include the appearance of facilities, personnel, and communication materials which aim to strengthen the impression of the quality of the services offered to service users (Patients)".

\section{Empathy}

Empathy is the ease of making relationships, good communication, understanding customer needs, and getting to know patients well, remembering problems (illnesses, complaints, etc.) (Ahmed et al., 2017; Bagozzi \& Moore, 1994; Shen, 2015). The results of the study indicate that the indicator of the Empathy variable is in the very good category. This proves that doctors, nurses and medical support officers in the Bahagia Hospital in Makassar City have a good communication relationship with patients, pay attention to patients, and understand well the needs of patients and families as service users. The better the patient's perception of empathy, the higher the patient's satisfaction. And if the patient's perception of Empathy is bad, then patient satisfaction will be lower. In line with research conducted by Fatas \& Wajdi (2017), the variable of caring (empathy) has a positive effect on patient satisfaction. This shows that empathy or a sense of concern and attentiveness shown by doctors, nurses, and medical support workers greatly affects patient satisfaction in being able to feel what is expected to recover and return. From Supartiningsih's research (2017) states that the psychological touch that nurses and other medical teams can convey to patients will reduce the stress they experience during illness, and it turns out that psychological fatigue contributes to the illness suffered by patients getting 
worse. Motivation from the medical team can reduce anxiety by providing emotional support in the form of patience, attention, motivation so that the patient will recover faster.

\section{Responsiviness}

Responsiviness is the ability of officers to provide services responsively and immediately, easy to access, does not wait long, is willing to listen to patient complaints (Sørum, 2014; Speer, 2012; West, 2004). The results of the study indicate that the Responsiviness variable indicator (responsiveness) is in the very good category, but this indicator is an indicator with the lowest percentage level of the five variables used. The results showed that the average patient agreed that doctors and nurses were responsive, nurses were easy to contact when needed, friendly and deft caring for patients. Basically, doctors, nurses and medical support officers are required with performance results that must be in accordance with the patient's expectations, which means punctuality, the same service for all patients without errors, a sympathetic attitude, and with high accuracy so that it will create a sense of satisfaction in oneself. the patient himself. The better the patient's perception of reliability, the higher the patient's satisfaction. And if the patient's perception of reliability is poor, the patient's satisfaction will be lower. In line with the results of research conducted by Idris E (2012) states that the variable reliability has a positive effect on patient satisfaction. In the research, Supriyanto \& Ernawati (2010) stated that from this aspect of reliability, apart from making the patient feel satisfied, the psychological impact that will occur is obedient behavior in the patient that can support his recovery.

\section{The level of satisfaction of inpatients at the Bahagia Hospital}

Patient satisfaction is the result of an assessment in the form of an emotional response (feelings of pleasure and satisfaction) to the patient because of the fulfillment of hopes or desires in using and receiving health services. This means that patient satisfaction is a function of performance and expectations. If the performance is below expectations, then the patient feels dissatisfied and vice versa.

To analyze the satisfaction of inpatients at the Hospital Bahagia Makassar City, based on service standards as stipulated in the Decree of the Minister for State Apparatus Empowerment Number KEP / M.PAN / 2004 which is then divided into 14 elements, namely: service procedures, service requirements, clarity of service officers, discipline service officers, responsibility of service officers, ability of service officers, speed of service, fairness of service, courtesy and friendliness of officers, fairness of service fees, certainty of service fees, certainty of service schedules, environmental comfort, and security of services.

The result of this research is that the percentage level of respondent's satisfaction with the quality of service is in the very good category, which means that inpatients at the Bahagia Hospital in Makassar City are satisfied with the services provided by the hospital. Although there are still elements of service that are deemed insufficient and need to be improved, such as justice in providing services to patients. This is in line with the opinion expressed by John Raws in Fattah (2013) that justice is a function of the structure of society, where people have the right to obtain Primary Goods which are the basic needs of society that every normal human being wants in everyday life. 


\section{6 | Jurnal Office: Jurnal Pemikiran Ilmiah dan Pendidikan Administrasi Perkantoran Vol. 7, No. 1, January-June 2021, Hal 21-28}

\section{The Influence of Service Quality on Decisions of Inpatients at the Bahagia Hospital Makassar City.}

Based on the results of data processing in this study, it shows that the quality of Bahagia Hospital is in the very good category and inpatient satisfaction is also in the very good category. The results of data processing using the SPSS ver 16.0 application obtained the R Square results of $40.5 \%$. This means that the quality of services provided by the hospital to patients and their families only has an effect of $40.5 \%$ and the other $51.5 \%$ is influenced by other variables. According to Budiastuti in Nooria (2008) other factors that can affect patient satisfaction are: product or service quality, emotional factors, price and cost.

\section{CONCLUSION}

Based on the results of research on the effect of service quality on inpatient satisfaction at Bahagia Hospital Makassar City. Then it can be concluded as follows: a) The quality of service at the Bahagia Hospital is already in the very good category. This can be seen from all the indicators that show support for the variable quality of service where the quality of service provided by the hospital is in accordance with the procedures and standards that have been previously set. Based on the opinions put forward by Zaithemal and Parasuraman, service quality is seen from the dimensions abbreviated to RATER (Realibility, Assurance, Tanggible, Empathy, and Responsivines), but the results obtained from this study are then sorted from the largest to the smallest percentage which is then shortened to ARTER (Assurance, Realibility, Tanggible, Empathy, and Responsivines); b) Satisfaction of inpatients at the Bahagia Hospital is in the very good category. Patient satisfaction increases because the quality of service provided by the hospital is in good condition and in accordance with predetermined rules and standards. Even though it is in the very good category, there are still variables that need to be improved and improved such as justice in providing services to patients; c) Service quality has a significant effect on patient satisfaction at the Bahagia Hospital. This can be seen from the data analysis showing the hypothesis which states that there is a positive and significant effect of service quality $(\mathrm{X})$ on patient satisfaction $(\mathrm{Y})$ is acceptable. The independent variable (service quality) on the dependent variable (patient satisfaction) has an influence of $40.5 \%$ and $51.5 \%$ is influenced by other variables such as product or service quality, emotional factors, prices and costs.

\section{REFERENCE}

Agency for Toxic Substances and Disease Registry. (2015). Public Health Statement: Toluene. In Public Health Service.

Ahmed, S., Tarique, K. M., \& Arif, I. (2017). Service quality, patient satisfaction and loyalty in the Bangladesh healthcare sector. International Journal of Health Care Quality Assurance. https://doi.org/10.1108/IJHCQA-01-2017-0004

Akib, H., \& Ihsan, A. (2017). Bureaucratic reform in public service: A case study on the one stop-integrated service. Mediterranean Journal of Social Sciences, 8(2), 253-258.

Ankeney, J. L. (1981). Assurance. Annals of Thoracic Surgery. https://doi.org/10.1016/S0003- 
4975(10)61042-9

Ayu, A., Niswaty, R., Darwis, M., \& Arhas, S. H. (2019). Applying the Principles of Good Governance in the Efforts of Guiding Out-of-School Children at Social Service Offices Takalar Regency. Jurnal Office, 5(2), 51-58.

Bagozzi, R. P., \& Moore, D. J. (1994). Public Service Advertisements: Emotions and Empathy Guide Prosocial Behavior. Journal of Marketing. https://doi.org/10.1177/002224299405800105

Bircan, İ., \& Gençler, F. (2015). Analysis of Innovation-Based Human Resources for Sustainable Development. Procedia - Social and Behavioral Sciences, 195, 1348-1354. https://doi.org/https://doi.org/10.1016/j.sbspro.2015.06.321

Björkman, I., \& Lu, Y. (1999). The management of human resources in Chinese-Western joint ventures. Journal of World Business, 34(3), 306-324. https://doi.org/https://doi.org/10.1016/S1090-9516(99)00021-8

Frazer, M. (2003). Quality assurance in higher education. In Quality Assurance In Higher Education. https://doi.org/10.4324/9780203209554

Heywood, P., \& Harahap, N. P. (2009). Health facilities at the district level in Indonesia. Australia and New Zealand Health Policy. https://doi.org/10.1186/1743-8462-6-13

Institute for Public Health Malaysia. (2015). National Health \& Morbidity Survey 2015. In Institute for Public Health, National Institutes of Health, Ministry of Health Malaysia, Kuala Lumpur.

Lahey, B. B. (2009). Public Health Significance of Neuroticism. American Psychologist. https://doi.org/10.1037/a0015309

Lamin, A., \& Livanis, G. (2020). Do third-party certifications work in a weak institutional environment? Journal of International Management, 26(2), 100742. https://doi.org/https://doi.org/10.1016/j.intman.2020.100742

Niswaty, R., Darwis, M., Andriani, D., Nasrullah, M., \& Salam, R. (2020). Fasilitas Perpustakaan Sebagai Media dalam Meningkatkan Minat Baca Siswa. Khizanah AlHikmah: Jurnal Ilmu Perpustakaan, Informasi, Dan Kearsipan, 8(1), 71-78.

Pittman, R. E. (2016). Public health service. In Pharmaceutical Public Policy. https://doi.org/10.1201/b19633

Pollard, B. J. (2003). Quality assurance. In Wylie and Churchill-Davidsons: A Practice of Anesthesia, Seventh Edition. https://doi.org/10.1017/s0263967x00033218

Salam, R., Rosdiana, Suarlin, \& Akib, H. (2014). The impact of policy on region expansion to office administrative services in barombong subdistrict of gowa district. International Conference on Mathematics, Science, Technology, Education and Their Applications (ICMSTEA) 2014.

Saleh, S., Arhas, S. H., Haerul, H., \& Nasaruddin, N. (2019). Utilization of Learning Media in Digital Simulation Subjects. Jurnal Office, 4(2), 79-90.

Shen, L. (2015). Targeting smokers with empathy appeal antismoking public service announcements: A field experiment. Journal of Health Communication. https://doi.org/10.1080/10810730.2015.1012236

Sørum, H. (2014). E-mail responsiveness in the public sector. Lecture Notes in Computer Science (Including Subseries Lecture Notes in Artificial Intelligence and Lecture Notes in 


\section{Jurnal Office: Jurnal Pemikiran Ilmiah dan Pendidikan Administrasi Perkantoran Vol. 7, No. 1, January-June 2021, Hal 21-28}

Bioinformatics). https://doi.org/10.1007/978-3-319-10178-1_6

Speer, J. (2012). Participatory Governance Reform: A Good Strategy for Increasing Government Responsiveness and Improving Public Services? World Development, 40(12), 2379-2398. https://doi.org/https://doi.org/10.1016/j.worlddev.2012.05.034

Stevenson, J. D. (2017). Quality assurance. In Project Management: A Reference for Professionals. https://doi.org/10.1201/9780203741771

Van Gobel, L., Akib, H., Tahmir, S., \& Made, A. (2015). Innovation Of Public Service In Meeting The Basic Needs In Gorontalo, Indonesia. International Journal of Academic Research, 7.

West, D. M. (2004). E-Government and the Transformation of Service Delivery and Citizen Attitudes. Public Administration Review. https://doi.org/10.1111/j.15406210.2004.00343.x

Zalatar, W. F. (2017). Service Quality and Customer Satisfaction in Fast Food Restaurants: A Customer Comparison Using Discriminant Analysis. DLSU Research Congress. 